\title{
LL-37 induced cystitis and the receptor for advanced glycation end-products (RAGE) pathway
}

\author{
Lindsi McCoard Roundy ${ }^{1^{*}}$, Wanjian $\mathrm{Jia}^{1^{*}}$, Jianxing Zhang ${ }^{2}$, Xiangyang $\mathrm{Ye}^{3}$, Glenn D. Prestwich ${ }^{2}$, \\ Siam Oottamasathien ${ }^{1 \#}$ \\ ${ }^{1}$ Department of Surgery and Division of Pediatric Urology, Primary Children's Medical Center, Salt Lake City, USA \\ ${ }^{2}$ Department of Medicinal Chemistry and Center for Therapeutic Biomaterials, University of Utah, Salt Lake City, USA \\ ${ }^{3}$ Department of Pharmacotherapy, Primary Children's Medical Center, University of Utah, Salt Lake City, USA \\ Email: " SIAM.OOTTAMASATHIEN@hsc.utah.edu
}

Received 16 May 2013; revised 21 June 2013; accepted 5 July 2013

Copyright (C) 2013 Lindsi McCoard Roundy et al. This is an open access article distributed under the Creative Commons Attribution License, which permits unrestricted use, distribution, and reproduction in any medium, provided the original work is properly cited.

\section{ABSTRACT}

To elucidate pathways in bladder inflammation, we employed our physiologically relevant LL-37 induced cystitis model. Based on inflammatory studies involving other organ systems implicating the receptor for advanced glycation end-products (RAGE), we first hypothesized that RAGE is critically involved in LL-37 induced cystitis. We further hypothesized that a common RAGE ligand high mobility group box 1 (HMGB1) is up-regulated in bladders challenged with LL-37. Finally, we hypothesized that NF-אB dependent inflammatory genes are activated in LL-37 induced cystitis. Testing our first hypothesis, C57BI/6 mice were challenged with either saline (control) or $320 \mu \mathrm{M}$ of LL-37 intravesically for $1 \mathrm{hr}$. After 12 or 24 hours, tissues were examined with immunohistochemistry (IHC) for RAGE, and both mRNA and protein isolation for respective qRT-PCR and Western Blot analysis. Our second hypothesis was tested by employing HMGB1 IHC. Testing our final hypothesis, qRT-PCR was performed investigating five genes: TNF $\alpha$, IL-6, IL-1ß, GM-CSF, COX-2. In control and LL-37 challenged tissues, IHC for RAGE revealed similar qualitative expression. Evaluation with qRT-PCR and Western Blot for RAGE revealed diminished expression at the mRNA and protein level within LL-37 challenged bladders. IHC for HMGB1 revealed a moderate qualitative increase within LL-37 challenged tissues. Finally, with the exception of TNF $\alpha$, all NF-KB dependent inflammatory genes yielded substantial up-regulation. We have employed our LL-37 induced cystitis model to gain insight towards a possible mechanistic pathway involved in

${ }^{*}$ Equal contribution by both authors.

\#Corresponding author. bladder inflammation. This work provides data for future studies involving the inflammatory ligand HMGB1, RAGE, and receptor pathways that activate NF-кB.

Keywords: LL-37; Cathelicidin; Bladder Inflammation; Bladder Fibrosis; Spina Bifida; Myelomeningocele; Interstitial Cystitis; RAGE; HMGB1; NF-Kappa B

\section{INTRODUCTION}

In order for the bladder to store urine it must be compliant (pliable). It is imperative that it can hold urine at low pressures. Failure of this results in elevated bladder pressure, transmitting urine to the kidney resulting in glomerular injury, renal parenchymal fibrosis and failure. Deposition of extracellular matrix (ECM) within the bladder wall is the main reason for loss of bladder wall pliability. What leads to excess ECM deposition and resultant fibrosis remains unclear, but accumulated evidence suggests that inflammatory cascades play a significant role. In response to inflammatory insult, bladder fibrosis occurs as part of a wound healing process and the accumulation of ECM proteins (collagen types I and III) [1]. Also, during chronic tissue damage fibroblasts undergo a process of activation and conversion to myofibroblasts that proliferate and produce ECM [2,3]. The end result is a non-compliant fibrotic bladder. Myelomeningocele (MMC)/spina bifida (SB) and interstitial cystitis (IC)/painful bladder syndrome (PBS) are both disease states that affect the urinary bladder. In both, chronic inflammation can lead to fibrosis and bladder non-compliance, further perpetuating the disease state. The underlying physiology involves inflammation, yet the exact mechanism is elusive; as a result, current treatment options are suboptimal [4-7]. 
We have previously published a novel murine model of inflammatory bladder disease using the human cathelicidin LL-37 peptide to induce physiologic bladder inflammation [8]. The exact inflammatory mechanism of action for LL-37 is not completely understood and responses are elicited through the activation of a number of cell-surface receptors and signaling pathways, depending on the cell type being studied and the responses being assessed. In addition to the important antimicrobial role of the cathelicidin LL-37, it also demonstrates immunomodulatory properties and triggers inflammation via the promotion of leukocyte chemotaxis, stimulation of mast cell degranulation, enhanced neutrophil function, induction of chemokines including IL-8, regulation of inflammatory responses (in part via NF- $\mathrm{KB}$ signaling), angiogenesis, and the increased expression of extracellular matrix components $[9,10]$. Relatively low concentrations of LL-37 (13 - $25 \mu \mathrm{M})$ can be cytotoxic against several eukaryotic cells, and pose a significant risk to human cells upon exposure [11]. We hypothesized that LL-37 induced bladder inflammation involves the receptor for advanced glycation end-products (RAGE) and a common RAGE ligand high mobility group box 1 (HMGB1), resulting in the activation of $\mathrm{NF}-\kappa \mathrm{B}$ dependent inflammatory genes.

To our knowledge, the RAGE pathway has not been described or implicated in inflammatory diseases of the bladder. RAGE is primarily involved in homeostasis and inflammation and is one of the primary receptors for high mobility group box 1 (HMGB1) [12]. RAGE, a multiligand receptor of the immunoglobulin (Ig) superfamily [13], is expressed on multiple cell types including polymorphonuclear leukocytes (PMNs), monocytes/macrophages, T and B lymphocytes, DC, EC, and mucosal epithelial cells [14]. There have been studies that implicate RAGE as a protective pathway in processes involving pulmonary fibrosis, specifically loss of RAGE signaling was found to yield more prominent fibrotic tissue responses [15-17]. Although most studies suggest that ligand activation of RAGE transmits cell surface signals to various intracellular pathways including NF- $\kappa \mathrm{B}$, a heterodimeric protein complex is responsible for a multitude of transcriptional programs that produce proinflammatory cytokines and enzymes such as TNF $\alpha$, IL-1 $\beta$, IL-6, and COX-2 [18-24]. The expression of RAGE also is controlled by the transcription factor activity of NF- $\kappa B$ [21] and activation results in increased cell surface expression of RAGE. This leads to amplification of the original signal, further exacerbating inflammation [25,26]. Despite studies identifying the role of NF- $\kappa B$ in the RAGE signaling pathway, the cellular effectors and molecular mechanisms of such activation remain unknown.

In the lower urinary tract, HMGB1 is ubiquitously expressed in urothelial cells and extracellularly liberated into urine [27]. During episodes of bladder tissue insult, high urinary levels of HMGB1 have been identified [27] signifying necrotic tissue injury. HMGB1 was first identified as a non-histone chromosomal protein involved in DNA binding [28] and later recognized as a pro-inflammatory cytokine mediating endotoxin lethality in mice [29]. It is predominantly a nuclear protein present in most eukaryotic cells where it stabilizes nucleosome formation and facilitates transcription [30-32]. However, others have reported that HMGB1 also functions extracellularly [29,33-36], although it lacks a classical secretion signal. HMGB1 can be liberated via two routes, either from necrotic cell death with passive leakage from the cell [37] and/or active secretion from activated monocytes, macrophages [29,38], mature dendritic cells [31], NK cells [39], and endothelial cells [34]. RAGE was first identified as the receptor for HMGB1. Thus, HMGB1 activation could both initiate and sustain a proinflammatory phenotype.

In this study we propose that LL-37 induced bladder inflammation involves RAGE, a common RAGE ligand HMGB1, and ultimately converges on NF- $\mathrm{KB}$ signaling. We investigated whether activation of these pathways in the bladder could be responsible for the sustained, proinflammatory phenotype.

\section{MATERIALS AND METHODS}

\subsection{Bladder Inflammation and Tissue Collection}

Experiments were performed in accordance with the Institutional Animal Care and Use Committee (IACUC) of the University of Utah. LL-37 induced bladder inflammation was performed as previously described $[8,40]$. Briefly, 8 to 12 -week old female C57BL/6 mice were catheterized, bladders emptied, then washed with $150 \mu \mathrm{L}$ of $0.9 \%$ sodium chloride and emptied. After washing, $320 \mu \mathrm{M}$ of LL-37 or saline (controls) were infused slowly and left indwelling for 1 hour. Tissues were harvested at either 12 or 24 hours and the bladders were split longitudinally. One section was fixed in $4 \%$ paraformaldehyde for histology and the other was either snap frozen in liquid nitrogen then stored at $-80^{\circ} \mathrm{C}$ for protein extraction, or placed in RNAlater (QIAGEN, Germantown, MD, USA) overnight at $4^{\circ} \mathrm{C}$ then proceeded to RNA isolation or stored at $-80^{\circ} \mathrm{C}$ for future use.

\subsection{Immunohistochemistry (IHC) for RAGE and HMGB1}

$5 \mu \mathrm{m}$ sections were deparaffinized then rehydrated through xylene and graded alcohols. Endogenous peroxidase activity was blocked with $1 \%$ Hydrogen peroxide in TBST for 20' and washed 3X in TBST for 3'. Antigen retrieval was performed (Vector laboratories, Burlingame, CA., Lot\# V0421). To minimize non-specific anti- 
body binding, sections were incubated for 60 ' in $5 \%$ FBS in TBS with $0.3 \%$ Triton X-100. Sections were incubated overnight at $4{ }^{\circ} \mathrm{C}$ with primary antibody (Goat-Anti Mouse RAGE 1:200 in blocking solution, R\&D, Minneapolis, MN, Lot\# AF1179; or Rabbit-Anti Mouse HMGB1, 1:1000 in blocking solution, Abcam, Cambridge, MA, Lot\# ab18256). Following $\mathrm{O} / \mathrm{N}$ incubation, slides were washed 3X in TBST for 3'. Sections were then incubated for 60' with biotinylated secondary antibody 1:2000, followed by Vectastatin Elite ABC Reagent (Vector Laboratories, Lot\# PK-6100) diluted in TBST for 30'. Between incubations, sections were washed $3 \mathrm{X}$ for 3 ' in TBST. For visualization of immunoreactivity sections were incubated in DAB peroxidase substrate for 20 - 40 sec. Sections were washed in $\mathrm{ddH}_{2} \mathrm{O}$, counterstained, and dehydrated. Negative controls included incubation with TBST in place of the primary antibody and no immunoreactivity was observed.

\subsection{Protein Isolation and Western Blot}

Bladder tissues stored at $-80^{\circ} \mathrm{C}$ were homogenized in ice-cold RIPA lysis buffer (Thermo Scientific, Rockford, IL) with the addition of protease inhibitor (Sigma Aldrich) and phosphatase inhibitor (Thermo Scientific, Rockford, IL) using a Mini-Bead Beater homogenizer (BioSpec Products, Inc. Bartlesville, OK, USA). Isolated total protein was quantified using the BCA method (PIERCE, Rockford, IL). Equal amounts of protein were electrophoresed on a $4 \%-12 \%$ SDS-polyacrylamide gel (InVitrogen) and subsequently transferred to a nitrocellulose membrane ( $0.45 \mathrm{~m}$, InVitrogen). The membrane was blocked in washing solution $(0.1 \%$ Tween 20 in PBS) containing $5 \%$ nonfat dry milk. The same primary antibody utilized for RAGE IHC was utilized for the Western Blot experiments. Secondary antibodies were incubated at room temperature for 1 hour in blocking solution. Proteins were visualized via ECLplus chemiluminescence reagents (GE healthcare life sciences, Pittsburgh, PA).

\subsection{RNA Preparation and Real-Time qRT-PCR}

Tissues were homogenized on ice with a hand homogenizor, then total RNA was purified according to manufacturer's instructions (Qiagen RNeasy fibrous mini kit, Germantown, MD, USA). cDNA synthesis was performed following manufacturer instructions (ABI, Foster City, CA). Primer's for all genes of interest (RAGE, TNF $\alpha$, IL-6, IL-1 $\beta$, GM-CSF, COX-2) were synthesized and purchased from Applied Biosystems (Foster City, CA). Gene expression was quantified using the Taqman Gene Expression Assay (ABI, Foster City, CA) on an Applied Biosystems 7900 HT instrument. The data sets were analyzed with normalization, variance stabilization, and $\log 2$ transformation. The $2^{-\Delta \Delta \mathrm{Ct}}$ method was utilized in the analysis for differences in relative gene expression [41].

\section{RESULTS}

\subsection{RAGE Immunohistochemistry Comparing Saline Control versus LL-37 Challenged Bladders}

To establish if baseline RAGE expression was present in normal bladders and to test for potential changes in RAGE expression after LL-37 challenge, both saline control and those exposed to LL-37 were subjected to RAGE IHC. Saline instilled control bladders harvested after 12 and 24 hours are demonstrated in Figures 1A and $\mathbf{B}$ (U-urothelium, SBM-submucosa, LP-lamina propria, SMC - smooth muscle cell layer).

LL-37 instilled bladders harvested after 12 and 24 hours are demonstrated in Figures 1C and D. In saline controls, strong RAGE immunoreactivity (brown stain)

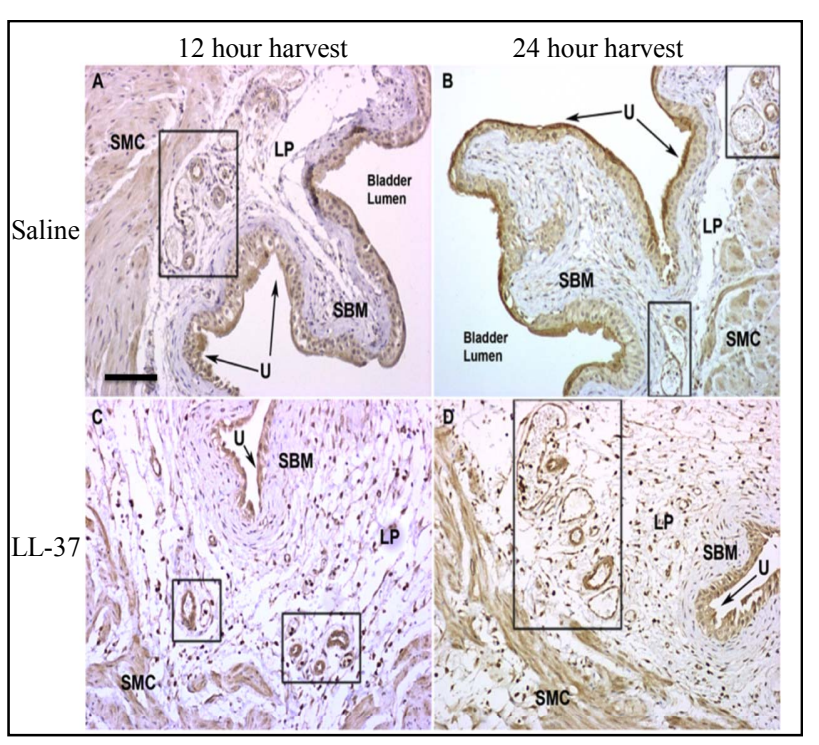

Figure 1. RAGE IHC comparing saline control vs. LL-37 challenged bladders. Saline controls after $12 \mathrm{~h} \mathrm{(A)}$ and $24 \mathrm{~h} \mathrm{(B)}$. LL-37 challenged bladders harvested after $12 \mathrm{~h}(\mathrm{C})$ and $24 \mathrm{~h}$ (D). U-urothelium, SBM-submucosa, LP-lamina propria, SMC - smooth muscle cell layer. In saline control bladders (A) \& (B), strong RAGE immunoreactivity (brown stain) was observed along the umbrella cells, with moderate intensity within the cytoplasmic regions in the urothelial (U) layer. No RAGE signal was observed in the SBM layer and LP, except for the arteriolar vessels had a moderate signal (rectangle). RAGE was detectable in the SMC layer. In LL-37 instilled bladders (C) and (D), similar RAGE expression patterns were observed compared to saline control tissues except for a qualitative loss of RAGE signal along superficial umbrella cells, but increased RAGE detection in the endothelium lining venules (D) (rectangle). In addition, numerous acute inflammatory cells were RAGE positive in both (C) and (D). Images reduced from $\times 10$, scale bar panel A represents $75 \mu \mathrm{M}$. 
was observed along the umbrella cells, with moderate intensity within the cytoplasmic regions in the urothelial (U) layer. No RAGE signal was observed in the SBM layer and LP, except for the arteriolar vessels had a moderate signal (rectangle). RAGE was detectable in the SMC layer. In LL-37 instilled bladders, similar RAGE expression patterns were observed compared to saline control tissues except for a qualitative loss of RAGE signal along superficial umbrella cells, but increased RAGE detection in the endothelium lining venules (Figure 1D - rectangle). In addition, numerous acute inflammatory cells were RAGE positive.

\subsection{HMGB1 Immunohistochemistry Comparing Saline Control versus LL-37 Challenged Bladders}

To help understand the impact of HMGB1 on LL-37 induced bladder inflammation, IHC was employed to determine HMGB1 expression patterns in both saline control versus LL-37 challenged bladders (Figure 2). In saline controls, HMGB1 immunoreactivity was apparent (brown stain) in all nuclei of the urothelium, myofibroblasts in the submucosa, endothelial cells of arterioles and venules, fibroblasts in the lamina propria, and

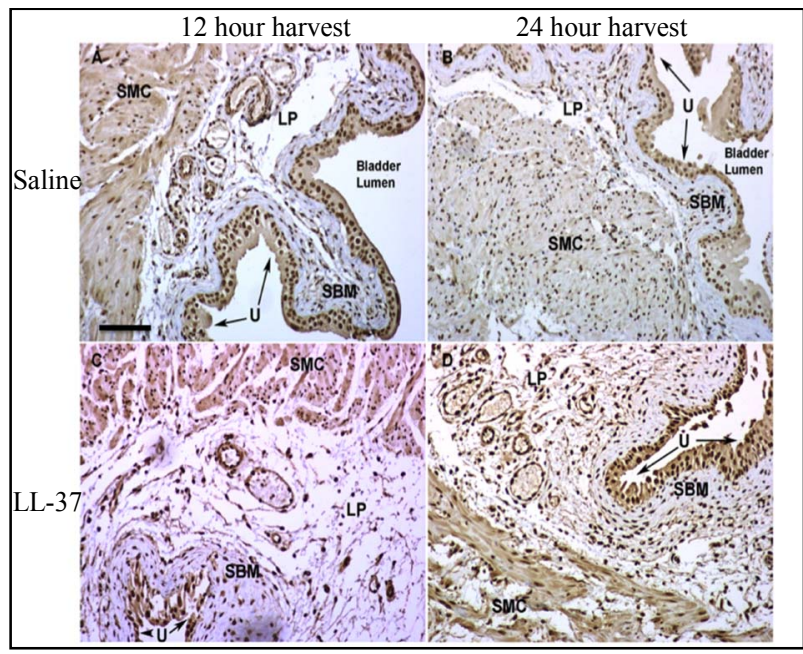

Figure 2. HMGB1 IHC comparing saline control versus LL-37 instilled bladders. Saline instilled control bladders harvested after $12 \mathrm{~h}$ (A) and $24 \mathrm{~h}$ (B). LL-37 instilled bladders harvested after $12 \mathrm{~h}(\mathrm{C})$ and $24 \mathrm{~h}$ (D). U-urothelium, SBM - submucosa, $\mathrm{LP}$-lamina propria, SMC - smooth muscle cell layer. In saline control bladders (A) \& (B), HMGB1 immunoreactivity was apparent (brown stain) in all nuclei of the urothelium (U), myofibroblasts in the SBM, endothelial cells of both arterioles and venules, fibroblasts in the LP, and smooth muscle cells. In LL-37 instilled bladders (C) and (D), similar ubiquitous HMGB1 immunoreactivity was observed compared to saline control tissues, except for positive detection in all acute inflammatory cells (primarily PMNs) within the inflamed tissues. Images reduced from $\times 10$, scale bar panel A represents $75 \mu \mathrm{M}$. smooth muscle (Figures $\mathbf{2 A}$ and $\mathbf{B}$ ). Analysis of the LL-37 instilled bladders showed similar ubiquitous HMGB1 immunoreactivity to saline control tissues, except for positive detection in all acute inflammatory cells (primarily PMNs) within the inflamed tissues, along with a qualitative increased staining pattern in the smooth muscle cell layer (Figures 2C and D).

\subsection{RAGE qRT-PCR and Western Blot}

In order to quantitate RAGE expression, both qRT-PCR and Western Blot methods were employed. In the qRTPCR experiments, total RNA was isolated from both saline control and LL-37 inflamed bladders. Tissue and RNA isolation was performed 24 hours after either saline or LL-37 exposure. LL-37 inflamed tissues demonstrated a near 10-fold reduction in RAGE RNA levels (Figure 3, red bar) when compared to saline controls (Figure 3, blue bar).

To quantitate the amount of RAGE protein in LL-37 challenged bladders, Western Blot analysis was performed (Figure 4). Lung tissue served as our positive control (Figure 4, lane A) (based on known robust expression levels of RAGE) and we identified diminished RAGE protein levels in our LL-37 challenged samples (Figure 4, lane B) versus saline instilled controls (Figure 4, lane $C$ ). Two bands were observed based on our antibody profile that detected both membrane-bound RAGE (55 kDa) and soluble RAGE (48 kDa). Normalization was carried out via baseline actin content. The diminished RAGE RNA expression patterns observed from the qRT-PCR results were further validated with decreased RAGE protein expression from our Western Blot experiments. Expression patterns observed from the

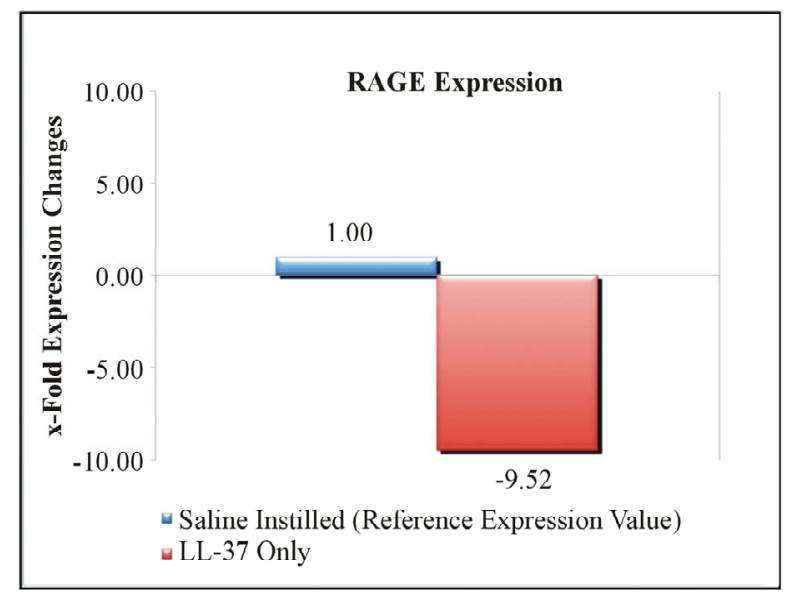

Figure 3. Quantitative RT-PCR of RAGE. Total RNA was isolated from both control and LL-37 inflamed bladders. Tissue and RNA isolation was performed $24 \mathrm{hrs}$ after either saline or LL-37 exposure. LL-37 inflamed tissues demonstrated a near 10-fold reduction in RAGE mRNA levels (red bar) when compared to saline controls. 


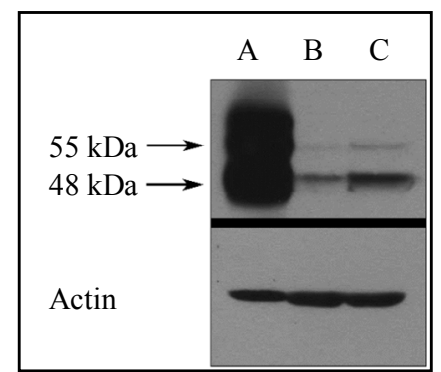

Figure 4. RAGE Western Blot. (A) - lung protein isolate (positive control), (B)-LL-37 instilled tissue harvested after 24 hours, (C) - saline instilled control tissue harvested after 24 hours. Two common RAGE bands were detected at $48 \mathrm{kDa}$ and $55 \mathrm{kDa}$. A moderate reduction in $\mathrm{RAGE}$ protein levels were observed within the inflamed LL-37 instilled bladders (B). Normalization carried out via baseline actin content.

qRT-PCR results were further validated with decreased RAGE protein expression from our Western Blot experiments.

\subsection{Downstream NF-кB Dependent Gene Expression}

HMGB1 signaling via RAGE can lead to the activation of NF- $\mathrm{kB}$. Therefore, we wanted to investigate five common downstream genes activated by NF- $\mathrm{KB}$ [18-24]. We hypothesized that LL-37 challenged tissues would yield up-regulation of all five genes (TNF $\alpha$, IL-6, IL-1 $\beta$, GM-CSF, COX-2) when compared to saline controls. To test this hypothesis, we utilized qRT-PCR from mRNA isolated in $12 \& 24 \mathrm{~h}$ tissues, for both LL-37 challenged bladders and saline controls. Figure 5 summarizes our results. With the exception of $\mathrm{TNF} \alpha$, all genes at both time points yielded substantial up-regulation when compared to controls.

\section{DISCUSSION}

Using our previously established model, we created bladder inflammation using the cathelicidin LL-37 [8,40], which has been found to be elevated in urine samples obtained from pediatric patients with either cystitis or pyelonephritis [42]. Profound bladder inflammation was observed after LL-37 exposure yielding global erythema, edema, hemorrhage, and hypervascularity. More severe tissue inflammation occurred in 24-hour versus 12-hour tissues [8]. IHC for RAGE identified expression along cytosolic and non-nuclear cellular membrane portions of the urothelium and smooth muscle, with strong RAGE expression in the acute inflammatory cells within LL-37 inflamed tissues. Overall RAGE expression, however, was down-regulated in LL-37 inflamed tissues. Western Blot analysis confirmed basal expression levels for RAGE in control tissues, with a moderate RAGE reducetion in inflamed bladders. As stated earlier, some lung studies have shown that a decrease in RAGE expression leads to fibrosis [15-17] and this appears to be true in the bladder between LL-37 and NF-KB, understanding only that LL-37 up-regulates inflammation through pathways that converge on NF- $\mathrm{KB}$. We attempted to show that LL37 induced bladder inflammation was connected to the signaling through RAGE and its various ligands.

Unexpectedly, a reduction in RAGE expression was noted in inflamed tissues compared to controls. Although, IHC for the RAGE ligand HMGB1 demonstrated moderate differences between control and LL-37 inflamed tissues. We mainly observed increased expression patterns in the acute inflammatory cells and smooth muscle cells within the inflamed samples. Despite diminished

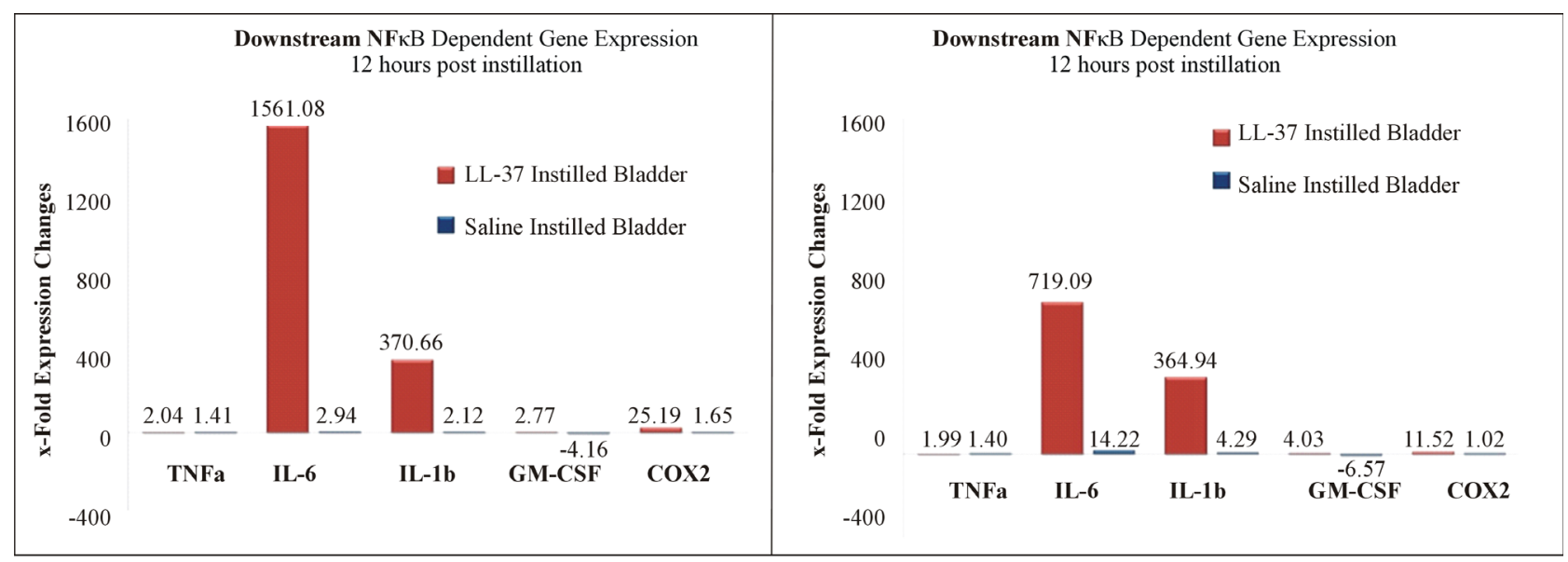

Figure 5. Quantitative RT-PCR for TNF $\alpha$, IL-6, IL-1 $\beta$, GM-CSF, \& COX-2. With the exception of TNF $\alpha$, all genes at both $12 \mathrm{~h}$ and $24 \mathrm{~h}$ time points yielded substantial up-regulation (red bars) when compared to controls (blue bars). 
RAGE expression, the moderate qualitative increase in HMGB1 expression seen in the inflamed tissues would suggest alternative receptor pathways are involved in the profound activation of NF- $\mathrm{KB}$ dependent genes. Again, four of five common downstream genes activated by NF-кB were substantially up-regulated within our LL-37 challenged tissues.

It has been well described that Toll-like receptors (TLRs), specifically TLR2 and TLR4, are involved in HMGB1 signaling [43-45]. HMGB1 can act as a ligand and bind not only the RAGE receptor [46], but TLR2 and TLR4. TLRs are a family of conserved proteins that enable cells of the immune system to respond to microbial structures. TLR2 has been shown to respond to grampositive components and fungi and TLR4 is the main receptor for endotoxin. Both TLR2 and TLR4 have been shown to be present in the lower urinary tract and bladder urothelium [27] and play a vital role in molecular defense mechanisms during urinary tract infection [47-49]. TLR2 also has been implicated in inflammatory responses in the urinary system and may play a role in progressive tissue fibrotic changes [50]. The signaling cascades initiated by TLR2 and TLR4 are complex. Similar to RAGE activation, the most prominent effect of TLR activation is the induction of NF- $\kappa B$ dependent gene expression. Overall, HMGB1 activation of TLR2 and/or TLR4 could both initiate and sustain a pro-inflammatory phenotype, ultimately explaining the increased expression of NF- $\mathrm{KB}$ dependent genes. With this knowledge, along with our data demonstrating such profound up-regulation of NF- $\mathrm{KB}$ dependent genes, further studies are needed to elucidate the role of TLRs.

\section{CONCLUSION}

We have innovatively employed our reproducible LL-37 induced cystitis model to gain further insight towards a possible mechanistic pathway involved in bladder inflammation. This work opens the door for future studies involving the inflammatory ligand HMGB1, RAGE, and the corresponding receptor signaling pathways that implicate NF- $\mathrm{KB}$.

\section{ACKNOWLEDGEMENTS}

Portions of this work have been supported in part by the following Grants: NIH SBIR 1R43DK093413 (SO, GDP, JZ) from the National Institute of Diabetes \& Digestive \& Kidney Diseases (NIDDK); NIH K12 Career Development Award in Children's Health Research UL1RR025764 (SO) from the University of Utah Center for Clinical and Translational Sciences (CCTS) and National Center for Advancing Translational Sciences (NCATS), American Urologic Association (AUA)/Pfizer Benign Urologic Diseases Award (SO), Primary Children's Medical Center Foundation Integrated Science Award (SO, GDP), Primary Children's Medical Center Foundation Early Career
Development Award (SO).

\section{REFERENCES}

[1] Deveaud, C.M., Macarak, E.J., Kucich, U., Ewalt, D.H., Abrams, W.R. and Howard, P.S. (1998) Molecular analysis of collagens in bladder fibrosis. The Journal of Urology, 160, 1518-1527. doi:10.1016/S0022-5347(01)62606-5

[2] Metcalfe, P.D., Wang, J., Jiao, H., Huang, Y., Hori, K., Moore, R.B. and Tredget, E.E. (2010) Bladder outlet obstruction: Progression from inflammation to fibrosis. $B J U$ International, 106, 1686-1694. doi:10.1111/j.1464-410X.2010.09445.X

[3] Wiseman, O.J., Fowler, C.J. and Landon, D.N. (2003) The role of the human bladder lamina propria myofibroblast. BJU International, 91, 89-93. doi:10.1046/j.1464-410X.2003.03802.x

[4] Lukban, J.C., Whitmore, K.E. and Sant, G.R. (2002) Current management of interstitial cystitis. Urologic Clinics of North America, 29, 649-660. doi:10.1016/S0094-0143(02)00055-1

[5] Theoharides, T.C. (2007) Treatment approaches for painful bladder syndrome/interstitial cystitis. Drugs, 67, 215235. doi:10.2165/00003495-200767020-00004

[6] Theoharides, T.C. and Sant, G.R. (2001) New agents for the medical treatment of interstitial cystitis. Expert Opinion on Investigational Drugs, 10, 521-546. doi: $10.1517 / 13543784.10 .3 .521$

[7] Toft, B.R. and Nordling, J. (2006) Recent developments of intravesical therapy of painful bladder syndrome/interstitial cystitis: A review. Current Opinion in Urology, 16, 268-272. doi:10.1097/01.mou.0000232048.81965.16

[8] Oottamasathien, S., Jia, W., McCoard, L., Slack, S., Zhang, J., Skardal, A., Job, K., Kennedy, T.P., Dull, R.O. and Prestwich, G.D. (2011) A murine model of inflammatory bladder disease: Cathelicidin peptide induced bladder inflammation and treatment with sulfated polysaccharides. The Journal of Urology, 186, 1684-1692. doi:10.1016/j.juro.2011.03.099

[9] Nijnik, A. and Hancock, R.E. (2009) The roles of cathelicidin LL-37 in immune defences and novel clinical applications. Current Opinion in Hematology, 16, 41-47. doi:10.1097/MOH.0b013e32831ac517

[10] Yamasaki, K., Di Nardo, A., Bardan, A., Murakami, M., Ohtake, T., Coda, A., Dorschner, R.A., Bonnart, C., Descargues, P., Hovnanian, A., et al. (2007) Increased serine protease activity and cathelicidin promotes skin inflammation in rosacea. Nature Medicine, 13, 975-980. doi:10.1038/nm1616

[11] Johansson, J., Gudmundsson, G.H., Rottenberg, M.E., Berndt, K.D. and Agerberth, B. (1998) Conformationdependent antibacterial activity of the naturally occurring human peptide LL-37. The Journal of Biological Chemistry, 273, 3718-3724. doi:10.1074/jbc.273.6.3718

[12] Hori, O., Brett, J., Slattery, T., Cao, R., Zhang, J., Chen, J.X., Nagashima, M., Lundh, E.R., Vijay, S., Nitecki, D., et al. (1995) The receptor for advanced glycation end 
products (RAGE) is a cellular binding site for amphoterin. Mediation of neurite outgrowth and co-expression of rage and amphoterin in the developing nervous system. The Journal of Biological Chemistry, 270, 25752-25761. doi:10.1074/jbc.270.43.25752

[13] Brett, J., Schmidt, A.M., Yan, S.D., Zou, Y.S., Weidman, E., Pinsky, D., Nowygrod, R., Neeper, M., Przysiecki, C., Shaw, A., et al. (1993) Survey of the distribution of a newly characterized receptor for advanced glycation end products in tissues. American Journal of Pathology, 143, 1699-1712.

[14] Yan, S.F., Du Yan, S., Ramasamy, R. and Schmidt, A.M. (2009) Tempering the wrath of RAGE: An emerging therapeutic strategy against diabetic complications, neurodegeneration, and inflammation. Annals of Medicine, 41, 408-422.

[15] Englert, J.M., Hanford, L.E., Kaminski, N., Tobolewski, J.M., Tan, R.J., Fattman, C.L., Ramsgaard, L., Richards, T.J., Loutaev, I., Nawroth, P.P., et al. (2008) A role for the receptor for advanced glycation end products in idiopathic pulmonary fibrosis. American Journal of Pathology, 172, 583-591. doi:10.2353/ajpath.2008.070569

[16] He, M., Kubo, H., Ishizawa, K., Hegab, A.E., Yamamoto, Y., Yamamoto, H. and Yamaya, M. (2007) The role of the receptor for advanced glycation end-products in lung fibrosis. American Journal of Physiology-Lung Cellular and Molecular Physiology, 293, L1427-1436. doi:10.1152/ajplung.00075.2007

[17] Queisser, M.A., Kouri, F.M., Konigshoff, M., Wygrecka, M., Schubert, U., Eickelberg, O. and Preissner, K.T. (2008) Loss of RAGE in pulmonary fibrosis: Molecular relations to functional changes in pulmonary cell types. American Journal of Respiratory Cell and Molecular Biology, 39, 337-345. doi:10.1165/rcmb.2007-0244OC

[18] Baldwin, A.S., Jr. (1996) The NF-kappa B and I kappa B proteins: New discoveries and insights. American Journal of Respiratory Cell and Molecular Biology, 14, 649-683. doi:10.1146/annurev.immunol.14.1.649

[19] Barnes, P.J. and Adcock, I.M. (1997) NF-kappa B: A pivotal role in asthma and a new target for therapy. Trends in Pharmacological Sciences, 18, 46-50. doi:10.1016/S0165-6147(97)89796-9

[20] Neurath, M.F., Pettersson, S., Meyer zum Buschenfelde, K.H. and Strober, W. (1996) Local administration of antisense phosphorothioate oligonucleotides to the $\mathrm{p} 65$ subunit of NF-kappa B abrogates established experimental colitis in mice. Nature Medicine, 2, 998-1004. doi:10.1038/nm0996-998

[21] Schmidt, A.M., Hori, O., Brett, J., Yan, S.D., Wautier, J.L. and Stern, D. (1994) Cellular receptors for advanced glycation end products. Implications for induction of oxidant stress and cellular dysfunction in the pathogenesis of vascular lesions. Arteriosclerosis, Thrombosis, and Vascular Biology, 14, 1521-1528. doi:10.1161/01.ATV.14.10.1521

[22] Stancovski, I. and Baltimore, D. (1997) NF-kappaB activation: The I kappaB kinase revealed? Cell, 91, 299-302. doi:10.1016/S0092-8674(00)80413-4

[23] Wang, X.C., Saban, R., Kaysen, J.H., Saban, M.R., Allen,
P.L., Benes, E.N. and Hammond, T.G. (2000) Nuclear factor kappa B mediates lipopolysaccharide-induced inflammation in the urinary bladder. The Journal of Urology, 163, 993-998. doi:10.1016/S0022-5347(05)67870-6

[24] Woronicz, J.D., Gao, X., Cao, Z., Rothe, M. and Goeddel, D.V. (1997) IkappaB kinase-beta: NF-kappaB activation and complex formation with IkappaB kinase-alpha and NIK. Science, 278, 866-869. doi:10.1126/science.278.5339.866

[25] Foell, D., Wittkowski, H. and Roth, J. (2007) Mechanisms of disease: A "DAMP" view of inflammatory arthritis. Nature Clinical Practice Rheumatology, 3, 382-390. doi:10.1038/ncprheum0531

[26] Schmidt, A.M., Yan, S.D., Wautier, J.L. and Stern, D. (1999) Activation of receptor for advanced glycation end products: A mechanism for chronic vascular dysfunction in diabetic vasculopathy and atherosclerosis. Circulation Research, 84, 489-497. doi:10.1161/01.RES.84.5.489

[27] See, W.A., Zhang, G., Chen, F., Cao, Y., Langenstroer, P. and Sandlow, J. (2009) Bacille-Calmette Guerin induces caspase-independent cell death in urothelial carcinoma cells together with release of the necrosis-associated chemokine high molecular group box protein 1 . BJU International, 103, 1714-1720. doi:10.1111/j.1464-410X.2008.08274.x

[28] Javaherian, K., Liu, J.F. and Wang, J.C. (1978) Nonhistone proteins HMG1 and HMG2 change the DNA helical structure. Science, 199, 1345-1346. doi: $10.1126 /$ science. 628842

[29] Wang, H., Bloom, O., Zhang, M., Vishnubhakat, J.M., Ombrellino, M., Che, J., Frazier, A., Yang, H., Ivanova, S., Borovikova, L., et al. (1999) HMG-1 as a late mediator of endotoxin lethality in mice. Science, 285, 248-251. doi:10.1126/science.285.5425.248

[30] Bianchi, M.E., Beltrame, M. and Paonessa, G. (1989) Specific recognition of cruciform DNA by nuclear protein HMG1. Science, 243, 1056-1059. doi:10.1126/science.2922595

[31] Lotze, M.T. and Tracey, K.J. (2005) High-mobility group box 1 protein (HMGB1): Nuclear weapon in the immune arsenal. Nature Reviews Immunology, 5, 331-342. doi:10.1038/nri1594

[32] Stros, M., Ozaki, T., Bacikova, A., Kageyama, H. and Nakagawara, A. (2002) HMGB1 and HMGB2 cell-specifically down-regulate the p53- and p73-dependent sequence-specific transactivation from the human Bax gene promoter. The Journal of Biological Chemistry, 277, 7157-7164. doi:10.1074/jbc.M110233200

[33] Merenmies, J., Pihlaskari, R., Laitinen, J., Wartiovaara, J. and Rauvala, H. (1991) 30-kDa heparin-binding protein of brain (amphoterin) involved in neurite outgrowth. Amino acid sequence and localization in the filopodia of the advancing plasma membrane. The Journal of Biological Chemistry, 266, 16722-16729.

[34] Mullins, G.E., Sunden-Cullberg, J., Johansson, A.S., Rouhiainen, A., Erlandsson-Harris, H., Yang, H., Tracey, K.J., Rauvala, H., Palmblad, J., Andersson, J., et al. (2004) Activation of human umbilical vein endothelial cells leads to relocation and release of high-mobility group box 
chromosomal protein 1. Scandinavian Journal of Immunology, 60, 566-573. doi:10.1111/j.0300-9475.2004.01518.x

[35] Rauvala, H. and Pihlaskari, R. (1987) Isolation and some characteristics of an adhesive factor of brain that enhances neurite outgrowth in central neurons. The Journal of Biological Chemistry, 262, 16625-16635.

[36] Rouhiainen, A., Kuja-Panula, J., Wilkman, E., Pakkanen, J., Stenfors, J., Tuominen, R.K., Lepantalo, M., Carpen, O., Parkkinen, J. and Rauvala, H. (2004) Regulation of monocyte migration by amphoterin (HMGB1). Blood, 104, 1174-1182. doi:10.1182/blood-2003-10-3536

[37] Scaffidi, P., Misteli, T. and Bianchi, M.E. (2002) Release of chromatin protein HMGB1 by necrotic cells triggers inflammation. Nature, 418, 191-195.

[38] Bonaldi, T., Talamo, F., Scaffidi, P., Ferrera, D., Porto, A., Bachi, A., Rubartelli, A., Agresti, A. and Bianchi, M.E. (2003) Monocytic cells hyperacetylate chromatin protein HMGB1 to redirect it towards secretion. The EMBO Journal, 22, 5551-5560. doi:10.1093/emboj/cdg516

[39] Semino, C., Angelini, G., Poggi, A. and Rubartelli, A. (2005) NK/iDC interaction results in IL-18 secretion by DCs at the synaptic cleft followed by NK cell activation and release of the DC maturation factor HMGB1. Blood, 106, 609-616. doi:10.1182/blood-2004-10-3906

[40] Oottamasathien, S., Jia, W., Roundy, L.M., Zhang, J., Wang, L., Ye, X., Hill, A.C., Savage, J., Lee, W.Y., Hannon, A.M., et al. (2013) Physiologic relevance of LL-37 induced bladder inflammation and mast cells. The Journal of Urology, S0022-5347(13)00014-1.

[41] Livak, K.J. and Schmittgen, T.D. (2001) Analysis of relative gene expression data using real-time quantitative PCR and the 2(-Delta Delta $\mathrm{C}_{\mathrm{T}}$ ) method. Methods, 25, 402-408. doi:10.1006/meth.2001.1262

[42] Chromek, M., Slamova, Z., Bergman, P., Kovacs, L., Podracka, L., Ehren, I., Hokfelt, T., Gudmundsson, G.H., Gallo, R.L., Agerberth, B., et al. (2006) The antimicrobial peptide cathelicidin protects the urinary tract against invasive bacterial infection. Nature Medicine, 12, 636641. doi: $10.1038 / \mathrm{nm} 1407$
[43] Park, J.S., Gamboni-Robertson, F., He, Q., Svetkauskaite, D., Kim, J.Y., Strassheim, D., Sohn, J.W., Yamada, S., Maruyama, I., Banerjee, A., et al. (2006) High mobility group box 1 protein interacts with multiple toll-like receptors. American Journal of Physiology Cell Physiology, 290, C917-C924. doi:10.1152/ajpcell.00401.2005

[44] Park, J.S., Svetkauskaite, D., He, Q., Kim, J.Y., Strassheim, D., Ishizaka, A. and Abraham, E. (2004) Involvement of toll-like receptors 2 and 4 in cellular activetion by high mobility group box 1 protein. The Journal of Biological Chemistry, 279, 7370-7377. doi:10.1074/jbc.M306793200

[45] Yu, M., Wang, H., Ding, A., Golenbock, D.T., Latz, E., Czura, C.J., Fenton, M.J., Tracey, K.J. and Yang, H. (2006) HMGB1 signals through toll-like receptor (TLR) 4 and TLR2. Shock, 26, 174-179. doi:10.1097/01.shk.0000225404.51320.82

[46] Huttunen, H.J. and Rauvala, H. (2004) Amphoterin as an extracellular regulator of cell motility: From discovery to disease. Journal of Internal Medicine, 255, 351-366. doi:10.1111/j.1365-2796.2003.01301.x

[47] Song, J. and Abraham, S.N. (2008) Innate and adaptive immune responses in the urinary tract. European Journal of Clinical Investigation, 38, 21-28. doi:10.1111/j.1365-2362.2008.02005.x

[48] Weichhart, T., Haidinger, M., Horl, W.H. and Saemann, M.D. (2008) Current concepts of molecular defence mechanisms operative during urinary tract infection. European Journal of Clinical Investigation, 38, 29-38. doi:10.1111/j.1365-2362.2008.02006.x

[49] Zasloff, M. (2007) Antimicrobial peptides, innate immunity, and the normally sterile urinary tract. Journal of the American Society of Nephrology, 18, 2810-2816. doi:10.1681/ASN.2007050611

[50] Leemans, J.C., Butter, L.M., Pulskens, W.P., Teske, G.J., Claessen, N., van der Poll, T. and Florquin, S. (2009) The role of toll-like receptor 2 in inflammation and fibrosis during progressive renal injury. PLoS One, 4, e5704. doi:10.1371/journal.pone.0005704 